PALOUŠ, R.: Filosofie jakožto výchova. Pedagogika, 1998, roč. 48, č. 2, s. 106-112.

PRŮCHA, J.: Vzdělávání a školství ve světě. Praha: Portál, 1991.

PRŮCHA, J.: Moderní pedagogika. Praha: Portál, 2008.

SAK, P. a kol.: Člověk a vzdèlání v informační společnosti. Praha: Portál, 2007.

SKALKOVÁ, J.: Výchova a vzdělávání v kontextu soudobých globalizačních tendencí. Pedagogika, 2000, roč. 50, č. 1, 13-23.

Zákon č. 111/1998 Sb., o vysokých školách a o změnĕ a doplnění dalšich zákoni̊ (Zákon o vysokých školách, 2006).

Jana Šemberová sember@zsf.jcu.cz

\section{VYZNAVAČ BUDDHISMU NA OŠETŘOVACÍ JEDNOTCE}

\section{ÚVOD}

Od roku 1990 se v ČR přechodně nebo trvale usidlují lidé $z$ různých kontinentů, př́slušníci mnohých kultur, náboženství i barvy pleti. Zdravotnická péče jim má být poskytována nezávisle na národnosti, etnickém původu, náboženství a vyznání, politických názorech, světových názorech, sociálním statusu, stáŕí, pohlaví, nemoci a zdravotním postižení.

Zdravotníci se však často kvưli neznalosti kulturních a sociálních specifik zejména u výrazně odlišných kultur zaměřují u klientůcizinců jen na zvládnutí příznaků a skryté potenciály těchto nemocných zůstávají nevyužity. Chceme-li lépe porozumět zdraví a nemoci v kontextu kultury, je hlubší pochopení života lidí v odlišných kulturách a sociálních situacích nezbytné.

\section{ZÁKLADNÍ INFORMACE O SPECIFIKÁCH OŠETŘOVÁNÍ VYZNAVAČŮ / SYMPATIZANTU゚ BUDDHISMU}

Buddhisté jsou skromní, dobrosrdeční a využívají jen to, co skutečně potřebují. Upřednostňují duchovní hodnoty nad materiálními.

V názoru na přijímání stravy jsou buddhisté rozděleni na vegetariány a na ty, kteři jedí maso, ale pod třemi podmínkami. Př́snými vegetariány jsou prŕvrženci škol mahajánového buddhismu. Podmínky pro buddhisty, kteř́ jedí maso, jsou, že neviděli a neslyšeli samotnou porážku zvířete a nemají důvod předpokládat, že zviŕe bylo zabito kvưli nim. Pro mnichy platí zákaz jíst syrové maso, včetně tygřího a sloního.
Platí pro ně i přísná sebekázeň v jídle, mohou jíst pouze 1 krát denně, a to dopoledne, po poledni už mohou prijímat pouze tekutou stravu. Někteří buddhisté se vyhýbají silně páchnoucím rostlinám jako cibule, česnek, pažitka a pórek. Jako náhradu používají pšeniční lepek (seitan), sóju, tofu, agar a jiné rostlinné produkty. Po každém jídle následuje krátká modlitba. Laici nemají v přijímání stravy žádná omezení, mohou konzumovat stravu masitou i vegetariánskou a jíst i několikrát denně. Je to plně na jejich rozhodnutí (Bubík, Fárek, 2005).

Sestra, která bude prijímat a ošetřovat klienta (pacienta s buddhistickým vyznáním), by měla tyto požadavky, co se týče stravy, respektovat a v rámci svých a nemocničních možností se snažit klientovi/pacientovi vyhovět.

Buddhisté věří, že součástí úspěšné léčby některých onemocnění je nutné použít vedle lékové terapie i duševní postupy, např́klad odhalení minulých zlých činů (zpověd'), zmenšení jejich síly mravními činy a zdržet se v budoucnosti takových činů. Velký důraz buddhisté kladou na prevenci a vznik onemocnění, na čistotu těla i duše. Mniši mají striktní zákaz konzumace opojných látek, užívání drog a kouření. V některých př́padech však zdravotní stav klienta/pacienta nedovoluje tento striktní zákaz dodržet. Proto je vhodné postup léčby předem konzultovat s ošetrujícím lékařem. Buddhisté se podle své doktríny vyhýbají extrémům, což se vztahuje také na užívání léků, transfuzi krve, očkování. Transplantaci orgánů nezavrhují, mohou být dárci i př́ijemci. Neodpouštějí odnětí života $\mathrm{v}$ jakékoli formě, ale pokud se nemocný už nemůže uzdravit a nemůže dále usilovat směrem k osvícení, může být daný souhlas k eutanazii. Potrat připouští jen ze závažných zdravotních důvodů.

Mniši jsou zvyklí vstávat v brzkých ranních hodinách. Svůj den začínají meditací. Meditace je složkou buddhismu, vede ke štěstí v tomto životě a k blahu v príšstím zrození. Pomáhá zvládat psychické problémy, meditujícího uklidňuje a vede k jeho sebeuvědomění. Meditace nevyžaduje žádnou zvláštní polohu, buddhisté/ sympatizanti ji mohou provádět v sedu po orientálním způsobu, při chůzi, vleže na lůžku, je-li člověk nemocen nebo nechce dávat najevo, že medituje. Meditaci lze provádět několikrát denně. Bylo by vhodné, aby sestra $\mathrm{v}$ rámci svých možností zajistila $\mathrm{k}$ meditaci klidné a tiché místo. Po- 
kud není možnost poskytnout mu samostatný pokoj, je dobré umístit jej alespoň na pokoj s vhodnou skladbou klientů/pacientů. Doba meditace je individuální, přibližně trvá 20-30 minut. Při meditaci se využívá naprosté mlčenlivosti, popř. vydávání hlásek. Zdravotnický personál by měl respektovat pŕítomnost materiálních věcí, které slouží $\mathrm{k}$ meditaci. Jedná se např. o obrázek, sošku Buddhy a malu (buddhistický „růženec“). Tento „růženec“ je modlitební šňùra se 108 perlami/korálky.

Buddhisté mají své svátky, během nichž mohou odmítnout vykonání různých zdravotních testů a léčebných postupů. Jedná se o tyto dny: 1. ledna, 15. února, 21. března, 8. dubna, 21. května, 15. července, 1. záŕí, 23. záŕí, 8. prosince, 31. prosince. Sestra by měla v rámci možností ve spolupráci s lékařem testy a léčebné postupy na tyto dny neplánovat.
Oslovování ortodoxního mnicha v nemocnici je možné jeho př́ijmením, popř. dle postavení. To vše na základě předchozí domluvy. Laiky oslovujeme jejich civilním jménem.

Buddhistické pohřební zvyky se liší zem od země. U buddhistů by mělo být ve chvíli, kdy člověk umírá, uloženo tělo do polohy zvané „spící lev“", do pozice, v níž vydechl naposledy Buddha. Umírající leží na pravém boku, levá ruka spočívá na levém stehně, pravá je umístěna pod bradou a uzavírá pravou nozdru. Nohy jsou nataženy a velmi mírně ohnuty. Ideálem pro umírajícího a velmi št'astnou událostí je přítomnost mistra, ale když to není možné, mohou mu velice pomoci jeho duchovní přátelé. Jejich přítomnost by měl zdravotnický personál tolerovat. Buddhisté uznávají pochování do země i kremaci (Kriste a kol., 2002).

\section{STANDARD OŠETŘOVATELSKÉ PÉČE}

Název standardu:

\section{ZÁSADY REALIZACE OŠETŘOVATELSKÉ PÉČE U VYZNAVAČŮ/SYMPATIZANTŮ BUDDHISMU V ÚSTAVNÍM ZDRAVOTNICKÉM ZAŘÍZENÍ}

\begin{tabular}{|l|l|}
\hline Charakteristika standardu: & Rámcový procesuální standard \\
\hline Ošetřovatelský cíl: & $\begin{array}{l}\text { Poznat specifika poskytované ošetřovatelské péče u vyznavačůsympatizantů } \\
\text { buddhismu. } \\
\text { (Využití modifikace modelu Madeleine Leiningerové při poskytování ošetř́ovatelské } \\
\text { péče vyznavačúm/sympatizantům buddhismu v ústavních zdravotnických zařize- } \\
\text { ních) }\end{array}$ \\
\hline Skupina péče: & Pacienti/klienti [P/K]-vyznavači/sympatizanti buddhismu \\
\hline Datum použití: & Nejméně 2x za rok, průběžně, nepravidelně \\
\hline Datum kontroly: & $\begin{array}{l}\text { Manažer/ka ošetřovatelství (manažer/ka kvality ošetřovatelské péče, hlavní sestra, } \\
\text { vrchní sestra, staniční sestra) }\end{array}$ \\
\hline Kontrolu vykonal: & Vedoucí sestra/odborný zástupce/manažer/ka ošetřovatelství \\
\hline Podpis zodpovědného pracovníka: & Bc. Mgr. Lenka Čoudková; doc. PhDr. Gabriela Sedláková, Ph.D. \\
\hline Standard vytvořil: & $\begin{array}{l}\text { Schéma ošetřovatelského modelu Madeleine Leiningerové (MODEL VYCHÁZEJÍ- } \\
\text { CÍHO SLUNCE) - neni součástí této publikace, dostupné u autorú }\end{array}$ \\
\hline Příloha standardu: & \\
\hline
\end{tabular}

\section{KRITÉRIA STRUKTURY}

S1 Pracovníci: sestra/porodní asistentka/ (dále jen ,sestra")

S2 Prostředí: ústavní zdravotnická zařízení

S3 Pomůcky: pomůcky na jednotlivé ošetřovatelské výkony a jiné pomůcky dle potřeby, schéma ošetřovatelského modelu Madeleine Leiningerové (MODEL VYCHÁZEJÍCÍHO SLUNCE)

S4 Dokumentace: zdravotnická/ošetřovatelská dokumentace 


\section{KRITÉRIA PROCESU}

1. Voblasti technologických faktorů vyznavačůl sympatizantů buddhismu:

P1 Zná základy buddhistické filozofie, tradiční způsoby ošetřování a faktory holistického zdraví této komunity.

P2 Ví, že buddhisté žijí velmi skromně.

P3 Chápe, že mniši technologické faktory využivají na učení a šíření buddhismu.

P4 Uznává, že laičtí vyznavači/sympatizanti buddhismu pracují a zajímají se o pokrok $\mathrm{v}$ technice.

P5 Ví, že buddhisté zdravotnická zařízení využívají, nebrání se prrípadné hospitalizaci.

P6 Zná, že buddhisté kladou velký důraz na prevenci a vznik onemocnění, na čistotu těla i duše.

P7 Respektuje využívání alternativní medicíny, používání prírodních produktů.

2. Voblasti náboženských a filozofických faktorů vyznavačùsympatizantů buddhismu:

P8 Je si vědoma toho, že kultura $\mathrm{P} / \mathrm{K}$ vyznávajícího buddhismus vychází z buddhistické filozofie a učení.

P9 Ví, že buddhismu učí, že každý člověk je zodpovědný za vlastní osud.

P10 Ví, že buddhisté nevěří ve stvořitele.

P11 Rozlišuje, že buddhismus je náboženskofilozofický systém.

P12 Ví, že buddhista je ten, kdo se přiklání k Buddhovi, dharmě a obci žáků (sanghze).

P13 Ví, že to, co jiná náboženství hledajî $\mathrm{v}$ bohu, buddhismus hledá $\mathrm{v}$ karmè.

P14 Ví, že buddhismus učí, že proces zrodu a smrti je koloběhem znovuzrození (reinkarnace) bez počátku.

\section{Voblasti rodinných a společenských faktorü:}

P15 Je si vědoma toho, že buddhisté kladou velký důraz na rodinu, na výchovu a vzdělávání dětí.

P16 Respektuje životní hodnoty, které uznávají vyznavači/sympatizanti buddhismu.

P17 Ví, že buddhismus neodpouští odnětí života $\mathrm{v}$ jakékoli formě, potrat připouští jen ze závažných zdravotních důvodů.

P18 Respektuje, že v buddhismu je základní sociální jednotkou obec (sangha), nikoli rodina či př́buzní.
P19 Je si vědoma toho, že partneři jsou si v manželství rovni.

P20 Zná pět mravních zásad, které stanovil Buddha pro všechny lidi (mnichy, laiky).

P21 Ví, že oslovování ortodoxního mnicha v nemocnici je možné jeho pŕ́jimením, popř. dle postavení, to vše na základě předchozí domluvy. Laiky oslovuje jejich civilním jménem.

\section{Voblasti kultury a životního stylu:}

P22 Zná a respektuje kulturní hodnoty $\mathrm{P} / \mathrm{K}$ vyznávajícího buddhismus.

P23 Ví, že dharma je etické a filozofické učení o vesmírném a mravním rádu ovládajícím tento svět a náš život.

P24 Ví, že nirvána je indické slovo znamenající doslovně „vyhasnutí, vyvanutí“.

P25 Ví, že Buddhovo učení je pro každého. Nikdo není vyloučen kvưli rase, pohlaví nebo barvě pleti.

P26 Ví, že buddhistický mladík (NOVIC = zájemce o členství v buddhistické obci) musí mít alespoň 8 let.

P27 Respektuje, že buddhisté mají své svátky, během nichž mohou odmítnout vykonání různých zdravotních testů a léčebných postupů.

P28 Ví, že umírající je uložený do polohy „spící lev“ (leží na PB, LHK spočívá na levém stehně, PHK je umístěna pod bradou, nohy jsou nataženy a velmi mírně ohnuty).

P29 Ví, že ideálem pro umírajícího je prítomnost mistra. Pomoci však mohou jeho duchovní prátelé.

P30 Ví, že buddhisté uznávají pochování do země i kremaci.

P31 Ví, že v názoru na přijímání stravy jsou buddhisté rozděleni na vegetariány a na ty, kteří jedí maso pod třemi podmínkami.

P32 Ví, že pro mnichy platí zákaz jíst syrové maso, včetně tygřího a sloního.

P33 Respektuje, že někteří buddhisté se vyhýbají silně páchnoucím rostlinám jako cibule, česnek, pažitka a pórek. Jako náhradu používají pšeniční lepek (seitan), sóju, tofu, agar a jiné rostlinné produkty.

P34 Ví, že po každém jídle následuje krátká modlitba.

P35 Ví a respektuje, že mniši jsou zvyklí vstávat v brzkých ranních hodinách. Svůj den začínají meditací. 
P36 Pozná, že buddhisté se podle své doktríny vyhýbají extrémům, což se vztahuje také na uživání lékủ, transfuzi krve, očkování.

P37 Ví, že transplantaci orgánů nezavrhují, mohou být dárci i př́ijemci.

\section{V oblasti politických a právních faktorů:}

P38 Je si vědoma toho, že buddhisté dodržují zákony a politicky se neangažují.

P39 Je si vědoma, že někteří buddhisté podporují strany zaměřené na ochranu životního prostředí.

\section{Voblasti ekonomických faktorů:}

P40 Respektuje, že buddhisté upřednostňujî duchovní hodnoty nad materiálními.

P41 Ví, že buddhisté jsou skromní, dobrosrdeční a využívají jen to, co skutečně potřebují.

P42 Je si vědoma toho, že buddhisté preferujî soběstačnost a nezávislost na druhé osobě.

P43 Ví, že je zvykem, že laici podporují mnišskou obec (sanghu) (mnichy/mnišky) po materiální stránce a fungují tak jako kontrola čistoty mnišského života.

\section{V oblasti vzdélávacích faktorů:}

P44 Je si vědoma toho, že buddhisté podporují vzdělávání.

P45 Ví, že posláním mnichů je laiky vyučovat Buddhovu učení a poskytovat jim duchovní oporu v obtížných životních situacích.

P46 Je seznámena s tím, že buddhisté pořádají meditačně vzdělávací kurzy, ozdravná cvičení.

\section{KRITÉRIA VÝSLEDKU}

V1 Sestra vyznavačům/sympatizantům buddhismu poskytuje ošetřovatelskou péči s využitím modifikace ošetřovatelského modelu Madeleine Leiningerové (MODEL VYCHÁZEJÍCÍHO SLUNCE).

V2 Sestra s P/K respektuje jeho „náboženstvi““.

V3 Sestra má vypracovaný ošetřovatelský plán, na jehož realizaci se podílí spolu s $\mathrm{P} / \mathrm{K}$.

V4 Sestra do dokumentace $\mathrm{P} / \mathrm{K}$ zaznamenává potřebné údaje související s ošetřovatelskou péčí.

\section{AUDIT STANDARDU č......}

Oddělení:

Auditoři:

Datum:

\begin{tabular}{|c|c|c|c|c|c|}
\hline \multirow{5}{*}{$\begin{array}{l}\mathrm{S} \\
\mathrm{T} \\
\mathrm{R} \\
\mathrm{U} \\
\mathrm{K} \\
\mathrm{T} \\
\mathrm{U} \\
\mathrm{R} \\
\mathrm{A}\end{array}$} & Kód & Kontrolní kritéria & Metoda hodnocení & ANO & $\mathrm{NE}$ \\
\hline & S1 & $\begin{array}{l}\text { Ošetřovatelskou péči poskytuje sestra, porodní asistent- } \\
\text { ka? }\end{array}$ & $\begin{array}{l}\text { Kontrola plnění kvalifikačních } \\
\text { požadavkủ v osobním spise }\end{array}$ & & \\
\hline & S2 & $\begin{array}{l}\text { Ošetřovatelská péče se poskytuje na standardním } \\
\text { oddělení ústavního zdravotnického zařízení? }\end{array}$ & Kontrola pracovního prostředí & & \\
\hline & S3 & Má sestra připravené potřebné pomúcky? & Kontrola pomůcek & & \\
\hline & S4 & Vede sestra ošetřovatelskou dokumentaci? & $\begin{array}{l}\text { Pohled do ošetřovatelské } \\
\text { dokumentace }\end{array}$ & & \\
\hline
\end{tabular}




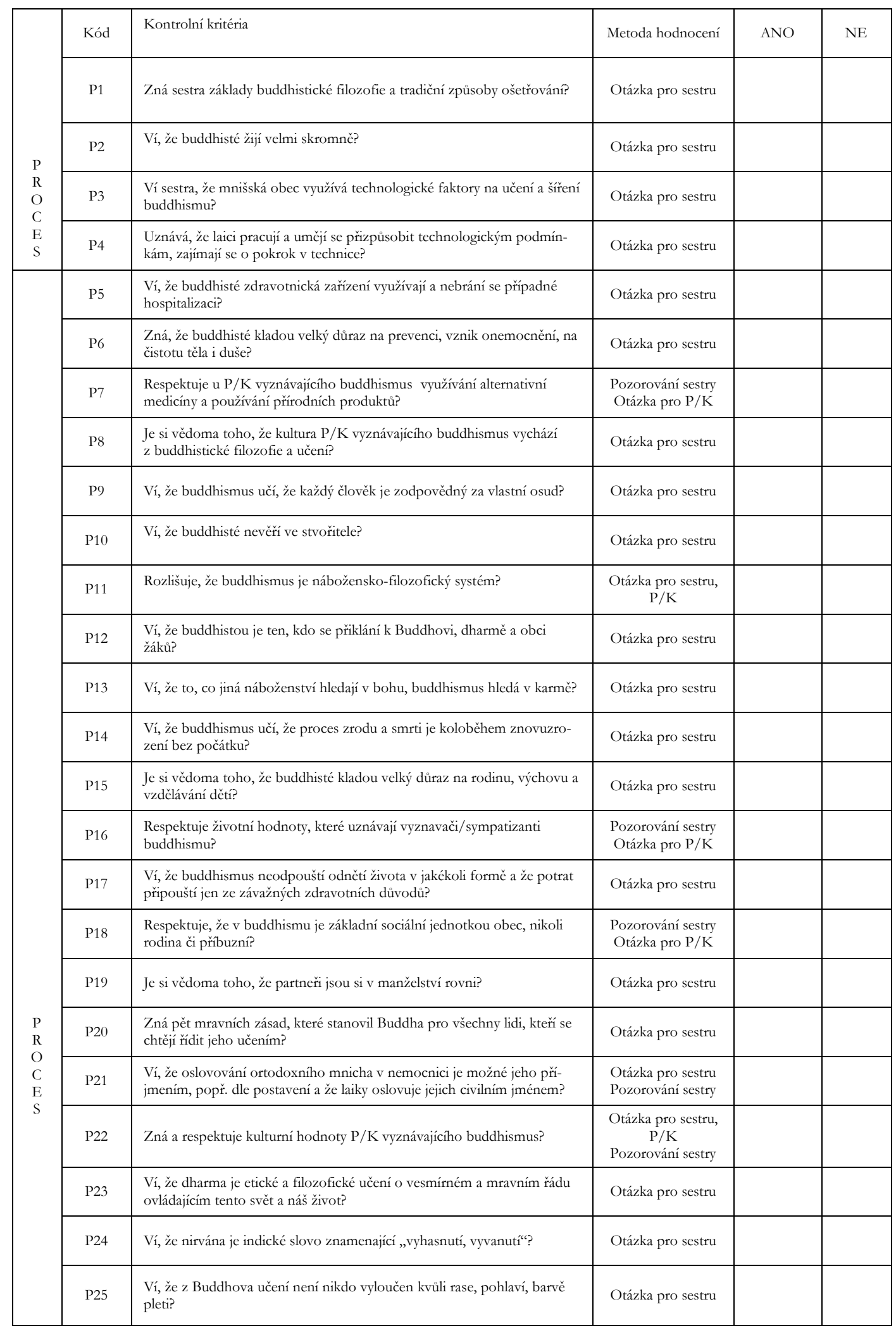




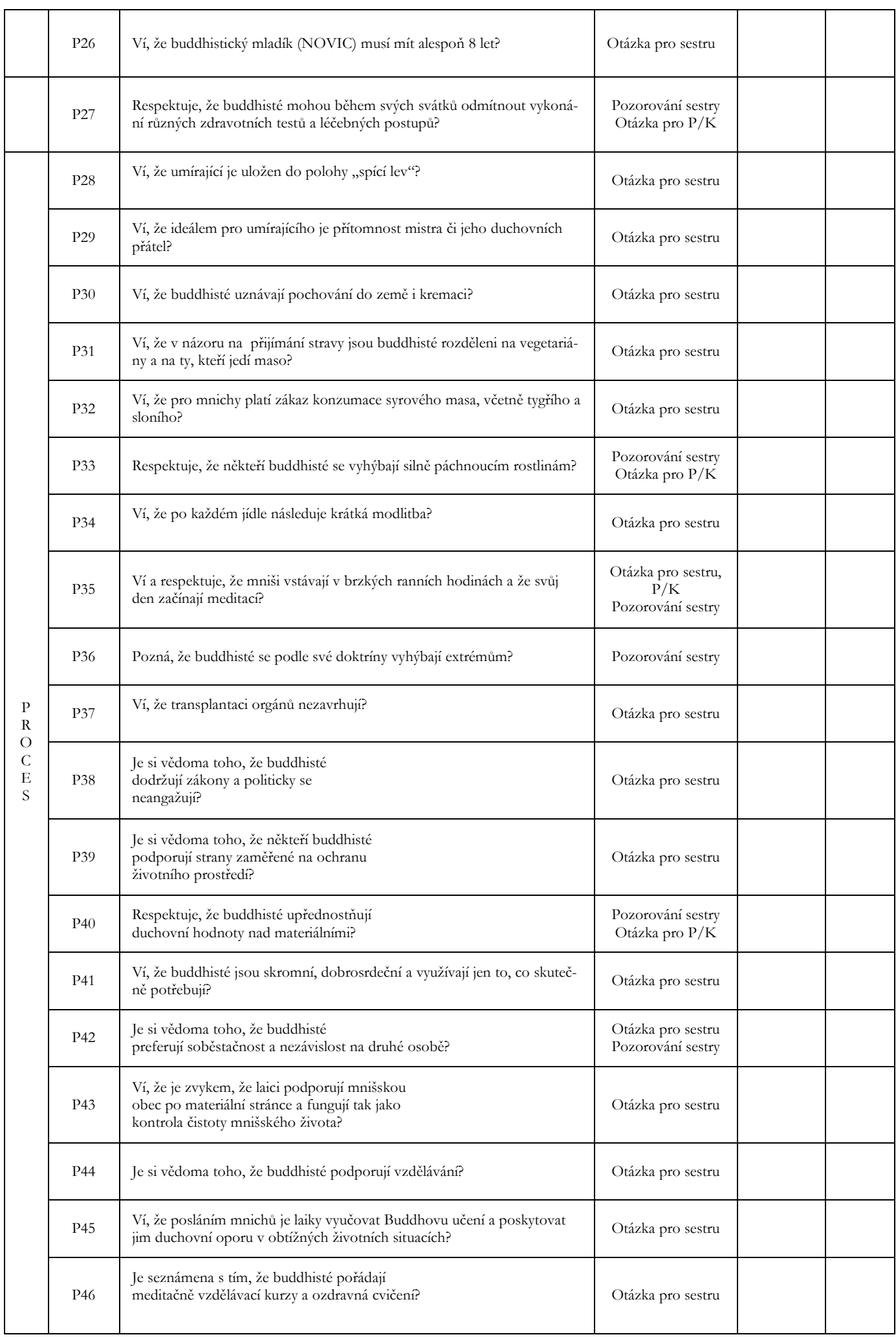




\begin{tabular}{|c|c|c|c|c|c|}
\hline \multirow{5}{*}{$\begin{array}{l}\mathrm{V} \\
\dot{Y} \\
\mathrm{~S} \\
\mathrm{~L} \\
\mathrm{E} \\
\mathrm{D} \\
\mathrm{E} \\
\mathrm{K}\end{array}$} & Kód & Kontrolní kritéria & Metoda hodnocení & ANO & $\mathrm{NE}$ \\
\hline & V1 & $\begin{array}{l}\text { Je } \mathrm{P} / \mathrm{K} \text { vyznávajícímu buddhismus poskytovaná } \\
\text { ošetřovatelská péče s využitím modelu Madeleine } \\
\text { Leiningerové? }\end{array}$ & $\begin{array}{l}\text { Otázka pro sestru } \\
\text { Pozorování sestry při ošetřovatel- } \\
\text { ské péči o } \mathrm{P} / \mathrm{K}\end{array}$ & & \\
\hline & V 2 & Respektuje sestra s P/K jeho náboženství? & $\begin{array}{l}\text { Pozorování sestry } \\
\text { Otázka pro } \mathrm{P} / \mathrm{K}\end{array}$ & & \\
\hline & V3 & $\begin{array}{l}\text { Má } \mathrm{P} / \mathrm{K} \text { vyznávající buddhismus vypracovaný } \\
\text { plán ošetřovatelské péče a podílí se na jeho } \\
\text { realizaci? Je informovaný, spolupracuje? }\end{array}$ & $\begin{array}{l}\text { Otázka pro sestru, } \mathrm{P} / \mathrm{K} \\
\text { Kontrola ošetřovatelské doku- } \\
\text { mentace }\end{array}$ & & \\
\hline & V 4 & $\begin{array}{l}\text { Jsou v dokumentaci zaznamenané potřebné údaje } \\
\text { související s ošetřovatelskou péčí? }\end{array}$ & $\begin{array}{l}\text { Kontrola ošetřovatelské doku- } \\
\text { mentace }\end{array}$ & & \\
\hline
\end{tabular}

* Vysvětlivky: $\mathrm{P} / \mathrm{K}$ - pacient/klient

\section{ZÁVĚR}

$\mathrm{S}$ nárůstem pŕílivu cizinců v posledních letech se stále víc otevírá otázka péče o jejich zdravotní stav. Představuje novou situaci, kterou je nutno řešit dříve, než se stane problémem. Při poskytování kvalitní zdravotní péče je třeba zohlednit klientovy etnické a kulturní hodnoty, názory a praktiky, které se vztahují k vlastnímu zdraví a k poskytování zdravotnické péče. Je zde nezbytné, aby každá sestra, která pracuje ve zdravotnickém zařízení, měla alespoň základní informace o specifikách ošetřování klientů odlišné kultury či etnika.

\section{LITERATURA}

BUBÍK, T., FÁREK, M.: Náboženství a jídlo. 1. vyd., Pardubice: Ceres, 2005. 188 s. dostupné z: http:// www.ceskatelevize.cz/vysilani/10084714986-prolinanisvetu/24675-narozeni-a-detstvi.html

IVANOVÁ, K., ŠPIRUDOVÁ, L., KUTNOHORSKÁ, J.: Multikulturní ošetrovatelství I. 1. vyd., Praha: Grada, 2005. $248 \mathrm{~s}$.

KONTROVÁ, L., ZÁČEKOVÁ, M., HULKOVÁ, V. a kol.: Štandardy v ošetrovatel'stve. Martin: Osveta, 2005. $215 \mathrm{~s}$.
KRISTE, R., SCHULTZE, H., TWORUSCHKA, U.: Svátky světových náboženství. Praha: Vyšehrad, 2002. $128 \mathrm{~s}$.

MASTILIAKOVÁ, D.: Transkulturní ošetřovatelství a globalizace zdravotní péče: jejich význam, zaměření na historická hlediska. In: Komunikace s cizinci při poskytování zdravotní péce: respektování jejich transkulturníl multikulturní odlišnosti v rámci českého právního rádu. 1. vyd., Ostrava: Ostravská univerzita, 2003. 120 s.

SEDLÁKOVÁ, G.: Buddhizmus a zdravie. Sestra, 2007. roč. VI. č. 1-2, s. 10-11.

SEDLÁKOVÁ, G.: Základy ošetrovania vyznávačov buddhizmu. Časopis moderního ošetřovatelství, Florenc, 2007. roč. III, č. 4, s. 165.

* Př́spěvek se vztahuje $k$ řšení grantového úkolu IGA MZ ĆR č. NS/9606-3, který byl realizován za finanční podpory IGA MZ ČR.

\section{Lenka Čoudková, Gabriela Sedláková lenka.coudkova@seznam.cz}

\section{MEZINÁRODNÍ RADIOBIOLOGICKÝ KONGRES PO 24 LETECH OPĚT V ČESKÉ REPUBLICE}

Ve dnech 26. až 29. srpna 2009 proběhl v Praze v hotelu Diplomat za účasti 180 odborníků z 18 zemí světa mezinárodní 37th Annual Meeting of the European Radiation Research Society. Celý kongres zorganizovala na základě pověření výboru The European Radiation Research Society Společnost pro radiobiologii a krizové plánování
České lékařské společnosti Jana Evangelisty Purkyně. Na organizaci této významné akce se podílela rovněž Společnost pro radiační onkologii, biologii a fyziku ČLS JEP a Ústav biofyziky Akademie věd České republiky v Brně.

Organizací této významné radiobiologické akce byla naše republika pověřena potřetí. Poprvé v roce 1967, podruhé v roce 1985. Na oba kongresy dosud pamětníci vzpomínají, a proto jsme pevně věřili, že i ten letošní si získá vysoký kredit. 